By demystifying western categories of "class," "kin" and "ethnicity," historicaltheologians could understand the martyrs - both Scillitan and in Carthage - to resist aligning themselves within the domus of the emperor because they are Africans who retained non-Roman constructions of kinship networks and an African identity.

\title{
3.4 Tertullian and Kinship Identity
}

Although Tertullian leaves few indications about his own kin, his relationship to his wife provides material for two of his works, Ad uxorem 1 and 2. In reviewing the argument of the two works, one notes the predominance of not only the subject of marriage and widowhood but also the multiplicity of kinship terminology used throughout the tracts. Ad uxorem 1 and 2 provide, therefore, a case study for kinship in Tertullian in which one can explore - at least partially his understanding of kin and kinship networks.

\subsubsection{Kinship in Ad uxorem 1}

From the initial sentence of Ad uxorem 1 Tertullian portrays the discussion in terms of a last will and testament to his wife which is written "to provide for the course which you must pursue after my departure from the world, if I shall be called before you; (and) to entrust to your honour the observance of the provision" (quid tibi sectandum sit post discessum de saeculo meum, si prior te fuero uocatus, iam hinc prouidere, ut prouisum obserues, mandare fidei tuae, 1.1.1). The direct address to his conserui (1.1.1; cf. 2.1.1), however, seems to be a rhetorical device, one which Tertullian uses to speak to "posterity" (posteritati, 1.1.2), which does not seem to imply physical children (1.5), but, as Tertullian concedes, could apply to "you, or to any other woman whatever who pertains to God" (tibi uel cuicumque alii feminae ad Deum pertinenti, 1.1.6). ${ }^{88}$ The specific

Tunis; likewise, probably in reliance on the Greek, some later manuscripts insert in ciuitate Tuburbitan minore, and the much later Acta 1.1, states that the arrest occurred apud Africam in ciuitate Turbitanorum. While debatable, this tradition at least suggests that successive African Christians understood these martyrs to be indigenous.

88 Dunn, Tertullian, 4. However, Hoffman, The Status, 161, assumes the letter is simply to his wife. Additionally, Tertullian implies that he is writing from an early period in their marriage (iam hinc, 1.1.1, 1.8.5). On conserui, which "within slave society the terms 'conservus' and 'collibertus' undoubtedly had all the force of kinship designations," see Flory, "Family in Familia," 89, and discussion above; Nathan, The Family, 46, interprets Tertullian's use of this title to indicate that "a wife's function was to serve her husband to the best of her ability, preferably in his attempt to uphold the tenets of their faith. The husband's rule, it may be 
content of his will is the desire that his "wife" (audience?) "after our departure, renounce nuptials" (post excessum nostrum renunties nuptiis, 1.1.4). Once the premise has been set forth, Tertullian supplements his will with arguments for why women should value the practice of uniuira (1.7.4).

Tertullian first clarifies that his request, renunties nuptiis, has no benefit for him personally, for "no restoration of marriage is promised in the day of the resurrection" (nulla restitutio nuptiarum in diem resurrectionis repromittitur, 1.1.4; ref. Lu. 20:36). He then gives a biblical-historical account of marriage first in Adam and Eve (1.2.1), followed by polygamy in the patriarchs (1.2.2), which was superceded by the Law (1.2.3), which in turn was "lopped off" (amputari) in Christ's "spiritual circumcision" (circumcisionem ...spiritalem). This line of reasoning sets up Tertullian's next (chrono-)logical step of agreeing with the Apostle Paul "who permits marrying indeed, but prefers abstinence" (permittente quidem nubere, sed abstinentiam praeferente, 1.3.2, ref. 1 Cor. 7). From this biblical account of marriage, Tertullian defends the ideals of virginity and uniuira. $^{89}$

Several objections face Tertullian's argument, and he, therefore, meets each of them so as to convince his wife/audience not to remarry. Among these objections are the claims that "the flesh is weak" (carnem ...infirmam, 1.4.1; ref. Mt. 26:41), that is a "fleshly concupiscence" (concupiscentia carnis, 1.4.2; cf. 1.4.3-5), and in turn a "worldly concupiscence" (concupiscentia saeculi, 1.4.2; cf. 1.4.6-7). After answering each of these objections, Tertullian provides examples from non-Christian religious practice where virgins and widows enact the ideals of continence (continentia,1.6.5). Finally, Tertullian argues that uniuira is the "will of God" (Dei uoluntate, 1.7.1), "even if you do not 'sin' in re-marrying" (etsi non delinquas renubendo, 1.7.3), because of"the honours which widowhood enjoys in the sight of God" (de uiduitatis honoribus apud Deum, 1.8.1, ref. Is. $1: 17-18)^{90}$

In book one, Tertullian writes didactically, arguing for the proper course of action for a Christian widow. He gives no indication that there is a person or party with whom he is disputing. Instead, Tertullian contrasts the Christian understanding of uniuira with the ideals of "the world" (saecula). The first sense in which Tertullian employs the concept refers to the sphere of departure for the Christians. He explains what his wife should do after his "departure from the world" (discessum de saeculo meum (1.1.1), which applies to all "Christians, after their departure from the world" (Christianis saeculo digressis, 1.1.4; cf. 1.7.1). The term has both spatial and temporal meanings, thus Tertullian speaks of the

inferred, was final, both in the matters of the marriage itself and as it pertained to the rest of the family."

89 These ideals do not seem to be identical with the alleged "celibacy" of Montanus, Prisc(ill)a and Maximilla. Trevett, "Gender," 16, claims Eusebius (ref. Historia ecclesiastica 5.18.3) documents how Prisc(ill)a and Maximilla left their husbands and rejects the testimony (Historia ecclesiastica 5.18.2) that Montanus sanctioned marriage annulment.

90 cf. 1.7.1-4; ref. 1 Tim. 2:2; Tit. 1:6; and 1 Tim. 5:9-10. 
"age of ages" (saecula saeculorum, 1.1.3) and "the last days of the (Jewish) age" (in extremitatibus saeculi, 1.2.4).

For Tertullian the spatio-temporal saecula generally includes the realm of ungodliness taken from biblical usage (e.g. 1.5.4; ref. 1 Cor. 10:11). Thus, he descriptively deems it "this most wicked world" (iniquissimo isto saeculo, 1.5.1), which marks a turn in the usage of saeculo in this treatise: from merely the sphere of departure and from the stronger, yet still non-specific, adjective, such as "worldly concupiscence" (saecularis concupiscentia, 1.4.2, 1.4.6, 1.5.3, 1.5.4), to the realm of wickedness explicitly ruled by Satan (satanae, 1.6.3) himself. The contrast between the Christian understanding of uniuira and that of the saecula invokes specific examples from "numbers of Gentile women" (pleraeque gentilium feminarum, 1.6.1; cf. 1.5.2, 1.6.3), namely,

At Rome, for instance, they who have to do with the type of that "inextinguishable fire," keeping watch over the omens of their own (future) penalty, in company with the (old) dragon himself, are appointed on the ground of virginity. To the Achaean Juno, at the town Aegium, a virgin is allotted; and the (priestesses) who rave at Delphi know not marriage. Moreover, we know that widows minister to the African Ceres. ${ }^{91}$

Although Tertullian lists examples from Greece and Africa to illustrate the practice among many "gentiles," his Roman example seems to be the most important, for he returns to the capitol for further elaboration claiming that in Rome "the king of heathendom, the chief pontiff" (Regem saeculi, pontificem maximum, 1.7 .5 ) reigns. ${ }^{92}$

By interpreting Tertullian's contrast of Christian uniuira with non-Christian or "gentile" practice as a contrast with Roman practice specifically one can better appreciate his comments on "worldly concupiscence" (saecularis concupiscentia). ${ }^{93}$ Tertullian describes it as "anxiety for posterity, and the bitter, bitter pleasure of children" (sollicitudine posteritatis et liberorum amarissima uoluptate, 1.5.1), both of which are values of the Roman familia. ${ }^{94}$ On this

91 1.6.3-4: Romae quidem quae ignis illius inextinguibilis imaginem tractant, auspicia poenae suae cum ipso dracone curantes, de uirginitate censentur. Achaicae Iunoni apud Aegium oppidum uirgo sortitur, et quae Delphis insaniunt nubere nesciunt. Ceterum uiduas Africanae Cereri adsistere scimus. On the rest of this quote, where the "widows" are said to "withdraw from their still living husbands" (in uita uiris ...decedunt), see Charlotte Methuen, "The "Virgin Widow': A Problematic Social Role for the Early Church?" HTR 90 (3 1997), 286; cf. Tertullian's rebuke of a "virgin widow" (uirgo uidua) in De uirg. uel. 9.

92 Note that Tertullian seems to be distinguishing the "Achaean Juno" from the Carthaginian goddess. Moreover, by emphasizing "African Ceres" his audience may understand the Libyan goddess which has undergone interpretatio Romana; on this phenomenon, see below, section 6.2 .

93 See Sider, Ancient Rhetoric, 130, for some of these themes in the classical rhetorical schools.

94 Dunn, Tertullian, 5, doubts this to be hyperbolic. cf. Tertullian's comments in De mon. 16.5-6, "What if a man thinks on posterity, with thoughts like the eyes of Lot's wife; so that a man is to make the fact that from his former marriage he has had no children a reason for repeating 
passage Nathan comments, "Tertullian was the first to thoroughly castigate the Roman ideal of wedded unions as a means to produce children. He rejected the notion of posterity and worldly ambitions as reasons for begetting offspring. ...This was the clearest rejection of traditional Roman marriages that had yet been voiced. ...A second marriage was tantamount to adultery, since it was, in Tertullian's eyes, associated with attraction of a worldly sort." 95 Tertullian elaborates on the motive to remarry, namely "glory, cupidity, ambition, want of sufficiency" (gloriam, cupiditatem, ambitionem, insufficientiam, 1.4.6), which "trumps up the 'necessity' for marrying" (necessitatem nubendi subornat). In other words, the Christian understanding of uniuira stands in opposition to the Roman values of familia.

Although uniuira can be found among "Gentile" religions, even Roman priests and priestesses, this is from

the devil given to his servants, and he is heard! He challenges, forsooth, God's servants, by the continence of his own, as if on equal terms! Continent are even the priests of hell! For he has found a way to ruin men, even in good pursuits; and with him it makes no difference to slay some by voluptuousness, some by continence. ${ }^{96}$

The Christian, according to Tertullian, must reject such understandings of familia and marriage, and she must embrace the practice "which scorns the world" (quae saeculum spernit, 1.8.3). Tertullian's use of kinship, especially marriage, in book one of Ad uxorem illustrates the centrality in his thought of Rome as symbolizing all things "gentile" which the "believers" (fidelibus, 1.4.7) of his Carthaginian congregation must reject.

Beyond epitomizing Rome as the realm of iniquity, Tertullian's use of kinship also presupposes an inherent connection between his understandings of kinship and class. In book one Tertullian connects widow's "marriage" to the Lord (dominus, 1.4.4, passim) with the economic implications of marriage in society at large. Christian widows are "wedded to God" (Deo nubere, 1.4.4),

marriage? A Christian, forsooth, will seek heirs, disinherited as he is from the entire world! He has 'brethren'; he has the Church as his mother. The case is different if men believe that, at the bar of Christ as well (as of Rome), action is taken on the principle of the Julian laws; and imagine that the unmarried and childless cannot receive their portion in full, in accordance with the testament of God" [Quid, si de posteritate quis cogitet isdem animis quibus oculis uxor Loth, ut ideo quis repetat matrimonium, quia de priore liberos non habuit? Heredes scilicet Christianus quaeret, saeculi totius exheres: habet fratres, habet ecclesiam matrem. Aliud est, si et apud Christum legibus Iuliis agi credunt et existimant caelibes et orbos ex testamento dei solidum capere non posse.] Tertullian's discussion of children is understood to be in response to the Roman ideal of children more than simply a "Judeo-Christian tradition"; however, see Suzanne Heine, Women and Early Christianity, (London: SCM Press, 1987), 29.

95 The Family, 44.

96 1.6.5: diabolus suis praecipit, et auditur. Prouocat nimirum Dei seruos continentia suorum quasi ex aequo: continent etiam gehennae sacerdotes. Nam inuenit, quomodo homines etiam in boni sectationibus perderet, et nihil apud eum refert, alios luxuria alios continentia occidere. 
and, to continue the analogy, to God "they assign their prayers as dowries" (Orationes suas uelut dotes ...assignant), and in so doing, they "are already counted as belonging to the angelic family" (de familia angelica deputantur).

The image of Christian widows transferring "dowries" to their new dominus stands in stark contrast to those of the "world" (saeculorum, 1.4.6) motivated by gloriam and ambitionem (1.4.6), who, upon entering into second marriages, wish "to lord it, (namely,) in another's family; to roost on another's wealth; to extort splendour from another's store, to lavish expenditure which you do not feel!" (dominari in aliena familia, alienis opibus incubare, cultum de alieno extorquere, sumptum quem non sentias, caedere). Moreover, God provides for the needs of "his servants" (seruorum suorum, 1.4.7), who do not desire "ponderous necklaces, not burdensome garments, not Gallic mules nor German bearers, which all add lustre to the glory of nuptial" (monilium pondera, non uestium taedia, non Gallicos mulos, nec Germanicos baiulos, quae nuptiarum gloriam accendunt). As recent anthropologists such as Schneider have found, isolating kinship from economics and other analytical categories artificially separates the informants' categories of meaning. In Tertullian, kinship and class coexist in thought and practice, because marriage includes dowries, wealth and the inheritance of one's familia.

\subsubsection{Kinship in Ad uxorem 2}

In book two, which Tertullian apparently wrote soon (proxime, 2.1.1) after $A d$ uxorem 1, the voice of the author again speaks directly to his "best beloved" (dilectissima) wife. Although Tertullian still emphasizes the preference for uniuira (2.1.2), he now "turns to the next best advice" (ad secunda consilia, 2.1.1): remarriage "in the Lord" (in Domino, 2.1.1), as opposed to, what Nathan called, "mixed marriages." " Allegedly, "in these days a certain woman" (quaedam istis diebus, 2.2.1) has married outside of the faith; therefore, in order that none may "deny that any formal warning has been given them" (negabunt sibi ...denuntiatum, 2.8.2) the author exposits "that utterance of the Apostle" (apostoli uox illa, 2.8.9) from 1 Corinthians chapter seven in fuller detail. ${ }^{98}$

The argument throughout book two deals with the problems of marrying a non-Christian, and so Tertullian begins by clarifying the Apostle Paul's letter to the Corinthian congregation, saying that "there is no scripture which holds forth a licence of this deed" (nulla scriptura eius facti licentiam profert, 2.2.1). Theologically, such marriages harm, not only the body of the woman, but the

97 The Family, 145.

98 However, $A d u x$. 2.3.2 could be read to indicate that at least one man was either marrying a nonChristian woman or supporting such marriages: "What did that man mean who said that "to wed a "stranger" was indeed a sin, but a very small one?"' [Quid sibi uoluit ille, qui dixit delictum quidem esse extraneo nubere, sed minimum...?] 
flesh and "blood of God. In hurting this flesh of ours, therefore, we hurt Him directly" (sanguine Dei. Laedentes igitur carnem istam, eum laedimus de proximo, 2.3.1). Spiritually, such marriages harm one's own "faith [which] undergoes a daily process of obliteration by unbelieving intercourse" (obliterari quotidie fidem commercio infideli, 2.3.3). Practically, the Christian would be unable to "discharge her duties" (officia pendat, 2.4.1) both to her husband and to God. Even tolerant husbands cause problems for the Christian woman eventually because of the suspicion and secrecy between the Christian and non-Christian (2.5). Ritually, "on all the memorial days of demons, [and] at all solemnities of kings" (illos omnibus honoribus daemonum, omnibus sollemnibus regum, 2.6.1) the spouse of a non-Christian will participate in idolatry, and in so doing she will "recognize a prejudgment of her own damnation" (praeiudicium damnationis suae agnoscet). ${ }^{99}$ Therefore, the Apostle Paul correctly distinguishes between those already married before conversion and Christians who marry outside of the faith (2.7). The final point of his argument, wherein Tertullian contrasts Christian marriage practices with those of non-Christian (2.8.1-5), concludes that the latter cannot compare to "the happiness of that marriage which the Church cements" (felicitatem eius matrimonii, quod ecclesia conciliat, 2.8.6). ${ }^{100}$

In book two of $A d$ uxorem a polemic replaces the didactic nature of book one, and, moreover, where the argument juxtaposed the familia of God with that of the saecula in book one, here Tertullian must speak more in terms of Christians and gentiles. The sixteen times Tertullian refers to "gentile matrimony" (matrimonio gentili) or some variant, such as a gentile husband, in contrast to the twice used saecula in book two, in that marriage to "unbelievers" (infidelibus, 2.2.2) is problematic "to a Christian" (Christiano), indicates the importance of the term. ${ }^{101}$

When Tertullian does invoke saecula in book two, however, he again indicates no disconnect between kinship and class. The spiritual harm arising from Christians marrying gentiles includes the concupiscentia saeculorum referenced in book one: "For in obeying a Gentile she will carry out Gentile practices - personal attractiveness, dressing of the head, worldly elegancies, baser blandishments" (Gentilem enim obseruando gentilia exhibebit: formam, extructionem, munditias saeculares, blanditias turpiores, 2.3.4). In his final remarks, Tertullian returns to this theme accusing any who marry gentiles as seeking "the concupiscences of worldly joys" (concupiscentias saecularium gaudiorum, 2.8.2), which, he explains,

99 Nathan, The Family in Late Antiquity, 145, says this is because the Christian wife "inevitably becomes a slave of her husband and thus must act as a pagan to be an obedient wife."

100 On the bishop's role in blessing a marriage, see Tert., De mon. 11.1; and De pud. 4.4.

101 For gentilium and variants in book two, see 2.2.1, 2.2.2, 2.2.3, 2.2.6, 2.2.7(2x), 2.2.9, 2.3.1, 2.3.4(3x), 2.5.1, 2.5.2, 2.7.1, 2.7.2(2x), 2.8.2 and 2.8.4. Compare this usage with book one, where gentilium only occurs in $1.5 .2,1.6 .1$ and 1.6 .3 , but saecula occurs sixteen times: 1.1 .1 , 1.1.2, 1.1.3 (2x), 1.1.4, 1.2.1, 1.2.4, 1.4.2, 1.4.6, 1.5.1, 1.5.3, 1.5.4 (2x), 1.7.1, 1.7.5 and 1.8.3. Nationes occurs only once in each work (1.7.5 and 2.8.1). 
is chiefly found among the wealthier; for the more any is rich, and inflated with the name of "matron," the more capacious house does she require for her burdens, as it were a field wherein ambition may run its course. ... [From where can such a one seek] a husband apt for maintaining their sedan, and their mules, and their hair-curlers of outlandish stature? ${ }^{102}$

The salience of the kinship/status connection in Tertullian becomes especially observable when taking account of his use of kinship imagery. ${ }^{103}$

Even apart from the use of concupiscentia saeculorum, Tertullian often attacks wealth. As proof that non-Christian husbands disrupt the practices of the Christian wife, Tertullian argues that when the woman wishes to be "visiting the brethren" (uisitandorum fratrum, 2.4.1-2) the husband insists on taking care of "family business" (familiae occupatio), especially when the visitation involves crossing lines of class or status, that is "indeed to all the poorer cottages" (quidem pauperiora quaeque tuguria). ${ }^{104}$ Tertullian's framework is the clash between the Christian domus, wherein the "Lord's Supper" (conuiuium dominicum, 2.4.2) is celebrated and "brethren" (fratrum, 2.4.3) may "kiss" (osculum), and the "alien home" (aliena domo, 2.4.3), which has no "guestchamber" (hospitium) for a "brother" (frater). ${ }^{105}$ Therefore, Tertullian elevates the risks of matrimonium gentilie by suggesting that the husband may use the "dowries" (dotes, 1.5.4) as blackmail, resulting in either "the extortion of their property, or else by the loss of their faith" (aut re excruciata aut fide perdita). In discussing "marriage of this

102 2.8.2: quidem plurimum in lautioribus deprehensum est. Nam quanto diues aliqua est et matronae nomine inflata, tanto capaciorem domum oneribus suis requirit, ut campum in quo ambitio decurrat, ... maritum petant idoneum exhibendae sellae et mulabus et cinerariis peregrinae proceritatis.

103 MacDonald, "The Role of Women in the Expansion of Early Christianity," in Early Christian Families in Context, ed. Balch and Osiek, 179

104 For frater in $A d u x$, see 2.2.1, 2.3.1, 2.4.2(2x), 2.4.3, 2.8.7, where the usage seems to be borrowed from the Apostle Paul (see esp. 1 Cor. 7:24). Contrast this usage with the single occurance in book one, where the "seven brothers" (septem fratribus, 1.1.5) who married one woman of Lu. 20:27-40 are referenced.

105 For comments on the familial kiss mentioned here by Tertullian, see Penn, "Performing Family," 156 and 162; cf. Penn's comments (159) on how husbands kissed their wives to check their breath for wine, a practice mocked by Tertullian, Apol. 6.4: "Under Romulus indeed one who had touched wine was put to death with impunity by her husband Metennius. For the same reason they were also even obliged to offer kisses to their kinsfolk, that they might be judged by their breath. Where is now that happiness of married life so successful in point of morals at any rate, the result of which was that for about six hundred years after the foundation of Rome a writing of divorce was unknown? But now in the case of women every part of the body is weighted with gold, no kiss is free owing to wine, and divorce is now the object of prayer, as the natural fruit of marriage" [sub Romulo vero quae vimum attigerat impune a Metennio marito trucidata sit. Idcirco et oscula propinquis offerre etiam necessitas erat, ut spiritu iudicarentur. Ubi est illa felicitas matrimoniorum de moribus utique prosperata, qua[e] per annos ferme sescentos ab urbe condita nulla repudium domus scripsit? At nunc in feminis prae auro nullum leve est membrum, prae vino nullum liberum est osculum, repudium vero iam et votum est, quasi matrimonii fructus]. cf. Tert., De prae. haer. 41 , where only the baptized kiss. 
kind" (huiusmodi matrimonium, 2.7.3), which "can in no case be carried to a prosperous end" (qua non dubites nullum ...prospere decurri), Tertullian transitions to his final point of comparison between Christian and non-Christian households.

In the closing lines of book two Tertullian explicates the comparisons of domus that will culminate all he has said heretofore. ${ }^{106}$ He describes how "even among the nations" (etiam penes nationes, 2.8.1) the heads of house, or "strictest lords" (seuerissimi ...domini), prohibit "their own slaves from marrying out of their house" (seruis suis foras nubere) as a means of protecting the household "goods" (dominica). Moreover, Tertullian invokes the right of the dominus to sell "such women" (quae) at large, for they "may be claimed as slaves" (seruituti uindicandas). The practice correlates, according to Tertullian, with Christian servants who "conjoin themselves with the devil's slaves" (diaboli seruos sibi coniugant, 2.8.2). ${ }^{107}$ Likewise, in reference to the concupiscentia saeculorum and those seeking ambitio, "the churches look paltry" (sordent ...ecclesia, 2.8.3) and no "rich man" (diues) is available in the "house of God" (domo Dei) but one may only be attained "from the devil" ( $a$ diabolo).

Tertullian counters such motives - ironically - with some of "the examples of Gentiles" (gentilium exempla, 2.8.4) who are not ashamed to marry "the ignoble and the mean" (ignobilibus et mediocribus) including "their own slaves and freedmen" (libere et seruis suis). Spiritually/economically/domestically, marriages to "the poor whose is the kingdom of heaven" (pauperum sunt regna caelorum, 2.8.5) benefit the woman, for "she will be dowried" (dotabitur) ultimately - by "God" (in Deo). The analogy is then completed with the imagery of a wedding ceremony:

Whence are we to find (words) enough fully to tell the happiness of that marriage which the Church cements, and the oblation confirms, and the benediction signs and seals; (which) angels carry back the news of (to heaven), (which) the Father holds for ratified? For even on earth children do not rightly and lawfully wed without their fathers' consent. ${ }^{108}$

106 A slightly different understanding from Nathan, The Family, 46, who says, "But Tertullian was not concerned with the domus. He was concerned with fidelity and conduct."

107 cf. a non-Christian husband as a "servant of the devil" [diaboli seruum, 2.4.1]. For Christians as serui of God, see 1.4.2, 1.4.7,1.5.1, 1.5.3, 1.6.5 and 2.8.7; cf. the Christian spouse as a conserua, in 1.1.1, 1.8.5, 2.1.1 and 2.8.7; for the verb, see 1.7.2, 2.1.2 and the quotation, "serve two lords" [duobus dominis seruire, 2.3.4]; ref. Mt. 6:24/Lu. 16:13. In addition, a Christian woman is to be a "handmaid of God" [Dei ancilla, 2.6.1]. On serui and conserui, see Flory, "Family in familia," 89.

108 2.8.6: Vnde sufficiamus ad enarrandam felicitatem eius matrimonii, quod ecclesia conciliat et confirmat oblatio et obsignat benedictio, angeli renuntiant, pater rato habet? Nam nec in terris filii sine consensu patrum rite et iure nubunt. For other mentions of the ceremony by Tertullian, see De idol. 16.3, for the wedding ring; De cor. 13.4, for the prohibition to wear crowns during the ceremony; De uirg. uel. 12.1 and De or. 22.4, for the kiss of the bride and groom - which 
Regarding this passage - one of the first references to any formal ceremony in Christian writing, Hunter warns, "We should not assume that the parallels Tertullian drew between Roman and Christian marriage practices should be taken literally. In Ad uxorem 2.8 Tertullian certainly wished to contrast a marriage between Christians with a marriage between a Christian and a pagan, but it is far from clear that he was describing a specifically Christian ritual of marriage." 109 Tertullian allows Christian marriages to be analogous to "gentile," or Roman, marriages, but simultaneously stresses the dissimilarity.

The North African ensconces his argument of marriage within the wider discourse on the domus, which permeates familial, economic, religious and political spheres. In order to further explore Tertullian's understanding of his identities and the identities of his community, the discussion will now turn to class theory. ${ }^{110}$

Treggiari, Roman Marriage, 147-53, disputes as a common practice. cf. discussion in Hunter, "Augustine," 89; and $A d u x .2 .3 .1$ and De uirg. uel. 12.1 for the marriage contract.

109 "Augustine," 70.

110 F. Forrester Church, "Sex and Salvation in Tertullian," Harvard Theological Review 68 (1975): 83-101, discusses several of these passages to argue that wealth was rejected by Tertullian for soteriological reasons (99); it is unclear if "soteriological" reasons exclude or outweigh socioeconomic ones. 